\title{
BACH, HANDEL, AND THE CHEVALIER TAYLOR
}

\author{
by
}

\author{
DAVID M. JACKSON
}

\begin{abstract}
But to proceed, I have seen a vast variety of singular animals, such as dromedaries, camels, \&ec and particularly at Leipsick, where a celebrated master of music, who had already arrived to his 88th year, received his sight by my hands; it is with this very man that the famous Handel was first educated, and with whom I once thought to have had the same success, having all circumstances in his favour, motions of the pupil, light, \&c but upon drawing the curtain, we found the bottom defective, from a paralytic disorder. ${ }^{1}$
\end{abstract}

THIs much-quoted paragraph from the autobiography of the peripatetic English oculist John Taylor is the basis for the tradition that he operated on both J. S. Bach, who was certainly the celebrated master of music at Leipzig, and his even more famous contemporary Handel. But, besides its off-hand linking of human geniuses with camels, the passage is so full of inaccuracies that many authorities, including Coats, who wrote an excellent biography of Taylor, have discounted his claim. ${ }^{2}$ Thus Bach died at the age of 65 , he did not regain his sight after operation, and, far from educating Handel, he never met him. But scholars have collected some external evidence that Taylor did operate on Bach and perhaps on Handel, though unhappily without success: the inaccuracies may merely reflect his general unreliability about details.

Bach and Handel were born in Germany within a month of each other in 1685, but their lives were very different. Johann Sebastian Bach, now generally regarded as the greater composer, was a retiring musician at churches and small courts in Germany. Though widely respected by musicians, he achieved little popular fame in his life, and after his death he was for long ignored, so that if you referred to 'Bach' you meant one of his sons-Christian in England or Emanuel in Germany. Handel, on the other hand, born the son of a humble barber-surgeon in Halle, became a musician against his father's wish, emigrated to England, and was soon a celebrity.

John Taylor was born in 1703 in Norwich, the son of a surgeon of the same name. He studied at St. Thomas's Hospital in London under William Cheselden, who was interested in eye surgery and had devised an operation for iridotomy. Taylor was successful, and was appointed to a hospital (probably in Norwich) while still young. In 1727 his book, An Account of the Mechanism of the Eye, dedicated to Cheselden, was published in Norwich. He decided to specialize in eye disease; in the preface to his autobiography he says that his profession is 'a part of physic distinct and independent of every other'. The title-page bears the motto 'Qui visum vitam dat' (who gives sight gives life), and on his coach, which was painted all over with eyes, was written a less neat version: 'Qui dat vivere, dat visere'. ${ }^{3} \mathrm{He}$ referred to himself as an 'ophthalmiater'-apparently a word of his own coining from the Greek for 'eye' and 'physician'-and was one of the first qualified surgeons to devote himself to diseases of the eye, at that time mostly the province of quacks. He began to travel to gain experience-and, doubtless, wealth. He toured the British Isles, then many countries of Europe: in his autobiography he calls himself the greatest of travellers, and most 


\section{M. Jackson}

of the work is taken up with anecdotes of his experiences in his wanderings. He claims to have seen men 'not to exceed 24 inches in height', 4 and describes the failure of an expected miracle when St. Lucia did not cure the sightless: 'I know not by what sins of the people that day no miracle appeared.' 5 Besides many noblemen, now forgotten, he operated on Edward Gibbon, and he claimed the acquaintance of many important men, including Van Swieten, who was the physician to the Empress of Austria. Van Swieten's son Gottfried was the Director of the Imperial Court Library in Vienna and helped and influenced many composers, including Haydn, Mozart, and Beethoven, by arranging concerts and by introducing them to forgotten masterpieces by Bach and Handel. Beethoven's First Symphony and Forkel's biography of Bach $^{6}$ are among many works dedicated to him. But his parsimony was notorious: it was he who caused Mozart's body to be thrown into a pauper's grave.?

Taylor acknowledges his pride in his showmanship, which seems to have been prodigious and effective. He was appointed oculist to King George II and to many European courts-though occasionally, where he was less successful, he would be banished. He was honoured by many continental schools and wrote many books, including the autobiography, which is in three volumes and is dedicated to his son John, who also became an oculist and practised in London, in Hatton Garden. It provides a fascinating picture of his personality and times but contains little of medical interest. His training seems to have been what was standard for surgeons of his day; he regarded himself as well qualified, and sought the approval of scholars. When he arrived in a new town he began by giving a lecture to the learned. Most of his contemporaries, however, were critical of his scientific writings and practices. ${ }^{8}$ It was common in his day for oculists to travel extensively-because, according to Coats, after the standard operation of couching, improvement was often temporary and the practitioner would leave town before the bad end-results were apparent. Taylor had operations for many conditions-ectropion, ptosis, corneal opacities, and even squint-according to Sorsby, ${ }^{\circ}$ he 'undoubtedly put squinting eyes straight'. He would sometimes operate for 'glaucoma', but, says Coats, ${ }^{10}$ his description of this condition is so vague that it is hard to know what he meant. In his early days he claimed to cure 'gutta serena' (a term used, before Helmholtz, for any form of blindness where the eye appeared normal to examination); later he modified this, claiming only to cure 'at least one species'-by rubbing the lower part of the globe with a silver spoon that had a rasp fixed to its convexity, or massaging the eye with its concavity. But like every other oculist of his day he had one standard operationcouching for cataract.

In this operation, a sharp, hooked needle or thorn was passed through the cornea or sclera into the opaque material and manipulated to break it up or 'couch' (depress) it below the level of the pupil.11 Couching was done in ancient times: it is mentioned in the Code of Hammurabi, which prescribed that the surgeon's fingers should be cut off if he failed, and by Susruta of ancient India. ${ }^{12}$ Elliot $^{13}$ describes two methods of couching practised in India in this century. In the anterior method, a needle or thorn was thrust suddenly through the cornea into the lens; the base of the needle was then elevated to depress the lens, immediately restoring sight. In the posterior method, the sclera was incised and a copper probe passed through and moved in a 


\section{Bach, Handel, and the Chevalier Taylor}

circle to break the suspensory ligament. The operation was relatively painless, and Elliot found vision of $1 / 3$ and up in over ten per cent, and $1 / 10$ and up in twenty per cent of patients. Failures were due to iritis, iridocyclitis, glaucoma, or imperfect dislocation.

Susruta described cataract as an opacity of the lens, but most later surgeons agreed with Galen that cataract was a concretion in the aqueous humour. ${ }^{14}$ About 1685 Maître-Jean had two patients in whom the couched matter was accidentally displaced into the anterior chamber instead of the vitreous, and turned out to be the lens. Later, Michael Brisseau found that the lens was opaque at a post-mortem in a soldier with cataract, and when he communicated his findings to the Royal Academy of Sciences in Paris, Maître-Jean supported him. ${ }^{15}$ Saint-Yves, when couching in 1722, accidentally displaced the lens forward and excised it-the first lens extraction in vivo. In 1745 Jacques Daviel accidentally broke the lens during couching and had to extract the fragments from the anterior chamber. Later he did this deliberately, and in another case while attempting couching he could not budge the lens downward so opened the cornea and extracted it-with excellent and permanent results. By 1756 he could report 434 extractions with only 50 failures: ${ }^{16}$ but couching and extraction both had partisans for another century. ${ }^{17}$

In Taylor's day, then, couching was still standard, but was beginning to be replaced by lens extraction as a treatment for cataract. In his early days his operation was simple couching. In A New Treatise on the Diseases of the Chrystalline Humour of a Human Eye (1736) he described Petit's operation-opening the capsule, making a hole in the vitreous, and pushing the cataract into it-but he probably seldom practised this elaboration. ${ }^{18}$ Though at times in his later life he sometimes extracted the lens, in general he frowned on extraction-perhaps because his peripatetic habits did not permit him to prescribe the spectacles needed to replace the lens. In the paragraph of his autobiography that follows the one about Leipzig, he describes the case of 'Mr. Owen, the bookseller, at Temple Bar, London', who had had an 'extraction of the Crystalline' in one eye by another surgeon; the sight there was 'almost useless from the absence of the crystalline, useless by a glass extremely convex'; that eye was scarred and irregular, unlike 'the eye where my hand has passed'-'where the glass maintains its healthful transparency, the pupil its natural figure and the crystalline being preserved in the eye has useful sight without a glass [sic], which cannot be from the other eye, and with a glass of not near the convexity of that used for the other, he sees with great perfection.' It is not clear how he attributes 'useful sight without a glass' to preservation of the crystalline if he really accepted the newer view that cataract was an opacity of the lens. ${ }^{19}$ In an advertisement issued in 1765 he claimed to use either method of treatment: ${ }^{20}$ but if the cataract was soft he would evacuate it by paracentesis, and if the mass of crystalline was very great he would remove it through a corneal incision. Postoperative care was not neglected: after couching, a mixture of Peruvian Balsam and warm water was dropped in the eye, then a cataplasm of the same with pulp of cassia was applied. 'Spirituous fomentations with camphire' were given on the second day and gentle evacuations were continued for twenty days. ${ }^{21}$

In the summer of 1749 Taylor set out on one of his European tours, and his travels 


\section{M. Jackson}

reported in the Berlin newspapers Vossische Zeitung and Spenersche Zeitung, are related by Lenth. ${ }^{22}$ Semi-miraculous cures were reported in the Netherlands: but physicians and professors of anatomy and surgery in Amsterdam warned the public that the rumours were mostly false. In December he visited Frankfurt and Cologne; he arrived in Leipzig on 27 March 1750, and next day gave a lecture and demonstration. By 1 April he had operated on Bach.

Johann Sebastian Bach, son and father of musicians, was born in Eisenach and orphaned at the age of ten. His musical genius was soon manifest and he was employed as church and court musician at Arnstadt, Mühlhausen, Weimar, and Cöthen. He came to Leipzig in 1723 to be appointed Cantor at St. Thomas's Church (though the authorities there would have preferred the more famous Telemann). His sight (always weak, according to his son) ${ }^{23}$ began to deteriorate; and according to Forkel, ${ }^{24}$ Bach's first biographer (who used much information from his sons Emanuel and Friedemann), he had a 'very painful disorder in the eyes'. His general health was probably poor, for in June 1749 the Church authorities had already interviewed one Gottlob Harrer 'for the future filling of the post of Capell-director there, upon the eventual occasion of the decease of Mr. Bach', ${ }^{25}$ and Harrer was in fact installed at Michaelmas in 1750. Bach had been working on The Art of Fugue, which many consider his masterpiece, but never began the last fugue of the projected series of twenty and broke off in the middle of the nineteenth, where the theme 'B-A-C-H-' (B flatA-C-B natural) appears in the counter-subject. ${ }^{26}$ (In the first edition, published two years after Bach's death, this fugue is omitted entirely, as it often is today in performance). Apparently it was Bach's eye-disease and general ill-health that prevented him from completing the fugue, ${ }^{27-29}$ though his son Emanuel wrote in the manuscript that he died while writing it. $^{26}$

According to the newspaper account, after the operation Bach 'recovered the full sharpness of his sight'. A second operation was done, ${ }^{23}$ though the newspaper accounts do not mention it. This was probably between 4 April, when the Spenersche Zeitung referred to his 'cure', and 8 April, for Taylor left Leipzig about then to arrive in Berlin on 14 April. His stay there was brief, for on 23 April the King ordered him to leave because of his failures.

Despite-or because of-these operations and drastic postoperative measures ('local irritations of the eye by repeated incisions and cataplasms with excessive use of the entire dubious armamentarium of the times'), ${ }^{30}$ Bach became blind. But he dictated at least one work to his son-in-law Johann Christoph Altnikol-an organ chorale based on the prelude 'Wenn wir in höchsten Nöthen sein': but he bade Altnikol to head the movement with the title of another hymn, "Vor deinen Thron tret ich hiemit' ('Before thy throne, my God, I stand'), the last verse of which has been translated:

Grant that my end may worthy be,

And that I wake thy face to see,

Thyself for evermore to know!

Amen, amen, God grant it so!'s

This chorale, though irrelevant, was added to the first edition of The Art of Fugue in place of the incomplete fugue. 


\section{Bach, Handel, and the Chevalier Taylor}

Soon afterwards, Bach suddenly recovered his sight, ${ }^{23}$ though some believe that this was a hallucination: $:^{32}$ but within a few hours he had an apoplectic fit. After ten days of coma and fever he died on $28 \mathrm{July}$. He was buried in the churchyard; and before long the grave was lost.

It was not long after this when Handel began to notice failing vision. In 1737 he had had a stroke with paralysis of the right arm, apparently with recovery. On 13 February 1751, a note he wrote in German in the score of Jephtha (an oratorio he was then composing) mentions weakening of the sight of his left eye; there is no mention of pain. Ten days later he was a little better, according to another note in the score. ${ }^{33} \mathrm{He}$ took the waters at Cheltenham Wells in May and June, and on returning to London consulted Samuel Sharp, who, like Taylor, was a pupil of Cheselden. Sharp, a surgeon to Guy's Hospital, was interested in cataract and had in 1740 suggested an improvement on Cheselden's iridotomy ${ }^{34}$ and in 1753 was to publish a new method of extracting the lens (using a sharp knife to cut the cornea). ${ }^{35,36}$ But apparently in Handel's case he found no evidence of cataract, for his contemporary Hawkins wrote that Handel 'was alarmed by a disorder in his eyes which, upon consulting with Mr. Samuel Sharp, Surgeon of Guy's Hospital, he was told was an incipient gutta serena'. ${ }^{37}$ In 1752, however, Handel was couched by William Bromfield, a surgeon to St. George's and the Lock Hospitals. Possibly some catastrophe had taken place since he had been seen by Sharp, for on 17 August 1752, the General Advertiser ${ }^{38}$ reported that he had been seized 'with a paralytick disorder in his head, which has deprived him of sight'.

There has been dispute as to the date of the operation. Deutsch ${ }^{38}$ quotes the General Advertiser of 4 November 1752: 'Yesterday, George Frederick Handel, Esq; was couch'd by William Bromfield, Esq; Surgeon to Her Royal Highness the Princess of Wales, when it was thought there was all imaginable Hopes of Success by the Operation, which must give the greatest Pleasure to all Lovers of Musick'. He believes that the date sometimes given, May 1752, is an error attributable to Schoelcher, ${ }^{30}$ who quoted the same passage (except for the spelling 'Bramfield') but attributed it to the Theatrical Register of 4 May 1752. The British Museum and other libraries I have consulted have no record of a journal of that title at that date, so perhaps Schoelcher's attribution is in error. He writes that this was the last of three operations (I have found no mention elsewhere of earlier operations), and adds: 'Alas, no! Blind he was to remain, as his mother had been in her old days.'

At first, after the operation, Handel saw well, but the success was short-lived, and on 27 January 1753, a newspaper (quoted by Schoelcher) reported: 'Mr. Handel has at length, unhappily, quite lost his sight'.

There is also doubt as to whether Handel was in fact completely blind. At times he would write (e.g. codicils to wills). He conducted and played the organ, and though he composed nothing new he revised his old works with the help of his pupil John Christopher Smith. Schoelcher ${ }^{40}$ found a pencil correction, which he thought was in Handel's handwriting, in the score of Jephtha in a quintet 'All that is in Hamor mine,' which was not in the original score, and probably was not added till 1756 or later.

In 1758 Handel and Taylor were both in Tunbridge Wells in August.41 'On the 


\section{M. Jackson}

Recovery of the Sight of the Celebrated Mr. Handel, by the Chevalier Taylor' was an anonymous poem dated 'Tunbridge Wells, 15 August' and published in the London Chronicle on 24 August. In it, Euterpe calls on Apollo and Aesculapius to help the blind Handel, but Apollo says that Aesculapius is not needed for Taylor will do it. ${ }^{42}$ This, apart from the claim in Taylor's autobiography, seems to be the only evidence that he operated on Handel. At all events Handel's sight was not restored but he continued to conduct. His health was deteriorating, however, and early in 1758 his appetite failed completely. On 6 April 1759, he fainted, and after a week of alternating coma and consciousness he died on the night of 13-14 April (whether on Good Friday, as he had hoped, or in the early hours of Easter Saturday, is not certain). He was buried in Westminster Abbey.

It is probably idle (though fascinating) to speculate on the causes of blindness and death in these two great composers. We have not, as we have for Beethoven, a necropsy record (though a skull thought to have been Bach's was examined by His with special attention to the temporal bone). ${ }^{32}$ We should not pretend to diagnosis in a living patient without complete history and examination; in the case of those long dead our suggestions are little better than guesswork. James ${ }^{43}$ suggests that Bromfield operated on Handel for a cataract that had appeared since Sharp's examination and that secondary glaucoma followed. He notes that Handel's death-mask shows a prominent right cornea suggesting a long-continued increase in pressure: but he admits that there is no record of Handel's being in pain after the operation. Arrington ${ }^{33}$ thinks that vascular disease is more likely. Hawkins ${ }^{44}$ refers to Handel's waiting for that 'crisis of his disorder in which he might hope for relief . . . by the help of manual operation': but it would be unsafe to deduce from this that by 'gutta serena' Sharp meant an immature cataract-and in the corresponding paragraph of Hawkins' second edition ${ }^{39}$ this reference is deleted. As to Bach, Baer ${ }^{32}$ and Scarlett ${ }^{45}$ suggest that Taylor believed that he had glaucoma-though Taylor's account of what he calls glaucoma is very vague-and Baer and Snyder ${ }^{30}$ both think that glaucoma was the true diagnosis. Terry ${ }^{31}$ suggests that Bach had chronic interstitial nephritis with retinitis. We can doubtless discount the emphasis laid by many writers on the harm done to Bach's eyes by long hours spent in copying music and playing from manuscripts in poor light. ${ }^{23,46,47}$

Of Bach's reaction to his blindness we know nothing: but Handel was bitter. In his Samson, written in 1741, he had called loss of sight 'worse than beggary, old age, or chains'; and Hawkins tells us that, when Sharp gave his opinion, Handel's 'spirits forsook him; and that fortitude which had supported him under afflictions of another kind, deserted him upon being told that a freedom from pain in the visual organs was all that he had to hope, for the remainder of his days. ${ }^{37}$ When Sharp suggested to Handel a partnership with the blind composer John Stanley, he replied angrily, 'Mr. Sharp, have you never read the Scriptures? Do you not remember? If the blind lead the blind, they both fall into the ditch' ${ }^{48}$ But it was not long before he sent for John Christopher Smith from France and with his help prepared an English version of his The Triumph of Time and Truth (originally written in Italian). This was more than a mere revision for it contained many new numbers-nine completely new. He revised other works and performed and conducted, though he composed no new 


\section{Bach, Handel, and the Chevalier Taylor}

large works. Often Smith and Stanley would help when his works were performed. Referring to the lines on blindness in Samson, Coxe ${ }^{49}$ wrote: 'The recollection that Handel had set this air to Music, with the view of the blind Composer then sitting by the Organ, affected the audience so forcibly, that many persons present were moved even to tears.'

Handel, the celebrity, probably thought of Bach as no more than a worthy local church musician though he respected him. Bach, on the other hand, held the highest opinion of Handel, copied out some of his works, and wished to meet him. Handel returned to Germany three times. ${ }^{50}$ In 1719 he visited Halle when Bach was at Cöthen nearby, and Bach went to Halle hoping to see him, but he had left the day Bach arrived. At his second visit, in the 1730s, Bach was ill and sent his son Friedemann inviting him to visit; but Handel regretted that he could not come. Bach had died before Handel's third visit. There is some irony in the fact that one of the few direct contacts between the two composers should be the man who operated unsuccessfully on both - 'the eye where his hand had passed' as blind in England as in Germany.

What sort of man was Taylor? He lived in an age when the blind were often decked with asses' ears and peacocks' feathers and exhibited in fairs as objects of amusement, ${ }^{\mathbf{} 1}$ and Taylor probably brought relief to many blind people, whatever his motives and however many his failures. He had studied with a genuine and eminent surgeon. Cheselden, a pupil of William Cowper, was surgeon to St. Thomas's Hospital from 1719 to 1738, and he became Master of the College of Surgeons after the split from the barbers; Pope was a patient of his. Moreover, Taylor had qualifications from several continental universities including Basle, Cologne, and Liège. (I have not been able to discover who-perhaps Taylor himself? - conferred on him the title of 'Chevalier'). Some of what he wrote (especially on squint) is regarded as sound by modern authorities. $^{2} \mathrm{He}$ had a conscience and (at least at some times in his career) would not operate if he thought success was unlikely or intervention dangerous. In his early days he advised leaving unilateral cataracts alone since an operation 'may be the occasion of the loss of both the eyes',52 and was aware of the importance of the pupillary reaction. At times he would use other methods of treatment: he describes his cure, by suggestion, of a nobleman who 'believed himself blind, by a hypochondriac disorder' ${ }^{53}$ It would be hard to better Coats' summary of Taylor, ${ }^{54}$ which ends with these words:

In professional matters his knowledge was good; he was a shrewd observer and not without original ideas; but his actual practice was deeply tainted with the dishonest arts of the quack. Many elements go to the formation of the complete charlatan-bombast, effrontery, dishonesty, ignorance. All these qualities Taylor showed in perfection-except ignorance, and this is his chief condemnation.

Of Taylor's life after 1761, when his autobiography appeared, little is known. He died, either in Paris or in a monastery near Prague, in 1772; and according to legend ${ }^{3,30}$ he was blind.

\section{REFERENCES}

I am particularly indebted to the authors of three works. The contemporary references to Handel are largely quoted from the book by Deutsch, ${ }^{28}$ and early references to Bach from 


\section{M. Jackson}

that by David and Mendel. ${ }^{\circ}$ Much of the material on Taylor is to be found in The Chevalier Taylor by George Coats, published originally in the Royal London Ophthalmic Hospital Reports, 1917,20 , and reprinted in pp. 132-236 of James's work. ${ }^{35}$ The page numbers given below refer to the works by Deutsch, David and Mendel, and Coats reprinted by James.

1. TAYLOR, J., The History of the Travels and Adventures of the Chevalier John Taylor, Ophthalmiater. Written by Himself, London, 1761, p. 25.

2. Conts, G., The Chevalier Taylor, p. 139.

3. Woods, S., Brit. J. Ophthal., 1930, 14, 193.

4. TAYLOR, J., op. cit., p. 59.

5. Ibid., p. 71.

6. David, H. T., and Mendel, A., The Bach Reader: A Life of Johann Sebastian Bach in Letters and Documents, New York, 1945, p. 294.

7. EinsteIn, A., Mozart, His Character, His Work, London, 1945, p. 148.

8. CoATs, G., op. cit., pp. 151-52.

9. SorsBy, A., A Short History of Ophthalmology, London, 1948, p. 63.

10. CoATs, G., op. cit., p. 190.

11. Singer, C., and Underwood, E. A., A Short History of Medicine, 2nd. ed., Oxford, 1962, p. 643.

12. KIRBY, D. R., Surgery of Cataract, Philadelphia, 1950, p. 3.

13. Elliot, R. H., Lancet, 1917, i, 325.

14. KIRBY, D. R., op. cit., p. 8.

15. Shastid, T. H., An Outline History of Ophthalmology, Southbridge, Mass., 1927, pp. 583-87.

16. Garrison, F. H., An Introduction to the History of Medicine, Philadelphia, 1929, p. 349.

17. SORBSY, A., op. cit., p. 51.

18. CoATs, G., op. cit., p. 176.

19. Ibid., p. 173.

20. Ibid., p. 179.

21. Ibid., p. 175.

22. LeNTH, B., Music and Letters, 1938, 19, 182.

23. BaCh, C. P. E., and AgricolA, J. F., Obituary of Bach, from Mizler's Musikalische Bibliothek, 1754; in DAVID and MeNDEL, op. cit., p. 220.

24. Forkel, J. N., 'On Johann Sebastian Bach's Life, Genius, and Works 1802', in David and MendeL, op. cit., p. 306.

25. David and Mendel, op. cit., p. 185.

26. Note in the hand of C. P. E. Bach in the manuscript of The Art of The Fugue, DAVID and MeNDEL, op. cit., illus. facing p. 256.

27. BaCH and Agricola, op. cit., p. 221.

28. Marpurg, F. W., Preface to The Art of the Fugue, 1752, David and Mendel, op. cit., p. 267.

29. FORKEL, J. N., op. cit., p. 340.

30. SNYDER, C., Archs. Ophthal., 1963, 69, 831.

31. TERRY, C. S., Bach, a Biography, 2nd ed., Oxford, 1950, p. 264.

32. BAER, K. A., Bull. med. Lib. Ass., 1951, 39, 206.

33. Arrington, G. E., Va. med. Mon., 1960, 87, 2.

34. SorsBy, A., op. cit., p. 60.

35. JAmes, R. R., Studies in the History of Ophthalmology in England Prior to the Year 1800, Cambridge, 1933, p. 97.

36. ChanCE, B., Ophthalmology, New York, 1962, p. 51.

37. Hawkins, J., History of the Science and Practice of Music, 2nd ed., London, 1853, p.910.

38. Deutsch, O. E., Handel: A Documentary Biography, New York, 1954, p. 726.

39. SCHOELCHER, V., The Life of Handel, London, 1857, p. 321.

40. Ibid., pp. 324-25. 
41. Baker, J., Diary, London, 1931 (quoted by Deutsch, op. cit., p. 804).

42. Deutsch, O. E., op. cit. p. 804.

43. JAMES, R. R., Music and Letters, 1932, 13, 168.

44. HawkIns, J., op. cit., 1st ed., London, 1776, p. 408.

45. SCARLETt, E. P., Archs. intern. Med., 1964, 113, 449.

46. Neuman, W., Bach: A Pictorial Biography, New York, 1961, p. 120.

47. PARrY, C. H. H., Johann Sebastian Bach, London, 1909, p. 541.

48. SADIR, S., Handel, London, 1962, p. 155.

49. Coxe, W., Anecdotes of G. F. Handel and J. C. Smith, 1799; quoted by H. Weinstock, Handel, New York, 1946, p. 297.

50. FORKRL, J. N., op. cit., p. 335.

51. GarRison, F. H., op. cit., p. 351.

52. COATs, G., op. cit., p. 174.

53. TAYLOR, J., op. cit., p. 36.

54. Conts, G., op. cit., p. 193. 